\title{
Proactive Alliance: Combining policing and counselling psychology
}

\author{
Charlotte Gill* and Molly C. Mastoras ${ }^{\dagger}$
}

This article is related directly to the $6^{\text {th }}$ International Law Enforcement $\mathcal{E}$ Public Health (LEPH) Virtual Conference in March 2021.

\begin{abstract}
The philosophy of community-oriented policing (COP) has been widely adopted by police departments around the world and has important benefits, such as improving community members' satisfaction with police and their perceptions of police legitimacy. However, implementing COP is challenging. Police departments report difficulties obtaining the support of officers on the ground and knowing how best to engage communities-which often contain multiple, overlapping, and sometimes competing groups within the same geographic area-in effective problem-solving and crime prevention.

This article describes Proactive Alliance, an innovative training program that draws from criminological theory and evidence-based principles in counselling psychology to teach police officers specific, immediately applicable techniques to establish rapport and long-term working relationships with community stakeholders. The training addresses two key challenges of COP: building meaningful collaboration across diverse communities and empowering frontline officers to become change agents in pursuit of the "co-production" of public safety. It builds on the original theory of broken windows policing, which emphasized the importance of harnessing police officers' personalities to facilitate successful community engagement and crime prevention, and provides practical tools based on those used by mental health professionals to enable officers to engage in active listening, to connect, and to problem-solve with the community while protecting their own well-being. We conclude by describing the potential of Proactive Alliance to strengthen COP and evidence-based policing more broadly.
\end{abstract}

Key Words Community-oriented policing; problem-solving; community engagement; mental health; police training; police officer wellness.

\section{THE CHALLENGE OF COMMUNITY COLLABORATION IN POLICING}

Community-oriented policing (COP) emphasizes community involvement in crime prevention efforts and positive, productive relationships between the police and community members, in contrast to traditional enforcement and order maintenance tactics. Community-oriented policing improves satisfaction with the police and has a modest favourable effect on perceptions of police legitimacy (Gill et al., 2014). Proactive policing strategies such as problem-oriented policing (POP) and broken windows policing also appear to be most effective at reducing crime when they are implemented in collaboration with the community (Braga et al., 2015; Weisburd et al., forthcoming; see also Goldstein, 1990; Office of Community Oriented Policing Services, 2014).
Despite the importance of community collaboration, and while a majority of the largest police departments in the United States have a community policing plan and/or dedicated personnel (Brooks, 2020; Hyland \& Davis, 2019; see also Trojanowicz et al., 1998), police leaders report difficulties in implementing COP, obtaining the support of officers on the ground, and-crucially-knowing how best to involve communities in problem-solving (Eck \& Rosenbaum, 1994; Mastrofski et al., 2007; Moore, 1992; Morabito, 2010; Skogan \& Frydl, 2004). A vast range of strategies have been deployed under the auspices of COP, some of which do not require community collaboration (Gill et al., 2014; Mastrofski et al., 1995; Skogan, 2006; Telep \& Weisburd, 2016). Similarly, POP — which has been described as the "tactical element" of COP (Cordner, 1999) — was originally conceptualized as a collaborative effort in which the police draw upon community

Correspondence to: Charlotte Gill, Department of Criminology, Law and Society, George Mason University, 4400 University Dr., MS 6D12, Fairfax, VA 22030, USA. E-mail: cgill9@gmu.edu.

To cite: Gill, C., \& Mastoras, M. C. (2021). Proactive alliance: Combining policing and counselling psychology. Journal of Community Safery and Well-Being, 6(3), 112-117. https://doi.org/10.35502/jcswb.193

@ Author(s) 2021. Open Access. This work is distributed under the Creative Commons BY-NC-ND license. For commercial re-use, please contact sales@sgpublishing.ca. g PUBLISHING Published by SG Publishing Inc. CSKA Official publication of the Community Safety Knowledge Alliance. 
expertise in problem-solving (Goldstein, 1990), but it rarely conforms to this definition in practice. A systematic review of POP found that only a few programs explicitly called for community collaboration, whereas others relied on traditional policing strategies or aggressive order maintenance (Weisburd et al., 2010; see also Braga \& Weisburd, 2019).

One reason for the lack of authentic community engagement in COP is that "community" is not homogeneous. In practice, police have to weigh the needs of different, overlapping, and sometimes even competing groups organized around various geographic, socio-demographic, and cultural characteristics. Communities also differ in their willingness to cooperate and collaborate with law enforcement. The police cannot expect to come into a community and begin collaborative problem-solving when their relationship with that community is strained or non-existent (Gill et al., 2014). Even when collaboration does occur, the police must proceed with caution. For example, officers working to maintain order in a nightlife district must be sensitive to the needs of business owners whose primary interest is in attracting as many patrons as possible to their bars and balance those needs against the needs of nearby residents who have concerns about disorder and noise.

In addition to the relationship with the community, the well-being of police officers themselves can also hinge on the successful implementation of community policing-and well-being is vital to successful police work (Lum et al., 2016). Research in this area is somewhat dated but shows that predictors of job satisfaction such as increased autonomy, creative thinking, increased control over outcomes, and increased task variety, task identity, and problem-solving skills are associated with the empowerment of officers that COP affords (e.g., Adams et al., 2002; Eck \& Rosenbaum, 1994; Greene, 1989; Johnson, 2012; Lurigio \& Skogan, 1994; Pelfrey, 2004; Rosenbaum et al., 1994; Zhao et al., 1999). However, officers only experience these benefits when they truly feel empowered and supported by their supervisors and organizations (Johnson, 2012). Furthermore, COP may increase officer stress and uncertainty if it is inconsistently implemented or if officers do not feel sufficiently trained and equipped to deal with new situations and responsibilities (e.g., Lord, 1996; Morash et al., 2006; Zhao et al., 2002). In contrast to traditional law enforcement, where the police are seen as the crime prevention "experts," some officers may perceive collaboration with community members on an equal footing as a threat to their autonomy (Skogan \& Hartnett, 1997; Skolnick \& Bayley, 1988).

\section{PROACTIVE ALLIANCE}

This article describes Proactive Alliance, an innovative training program grounded in evidence-based psychological principles that teaches police officers specific, immediately applicable techniques with a goal of establishing both a short-term rapport and long-term working relationships with community stakeholders. Proactive Alliance aims to address the challenges of collaborative police-community problemsolving by training officers to target individual interactions between specific people and agencies and navigate those relationships to meet the needs of all stakeholders on an ongoing basis. The program builds upon and enhances COP by developing knowledge, awareness, skills, and abilities that empower police officers to become change agents in the pursuit of public safety.

\section{Proactive Alliance and Community Building}

Proactive Alliance taps into key principles from broken windows theory (Kelling \& Wilson, 1982), which proposes that low-level disorder in communities generates more serious crime by increasing fear, isolation, and withdrawal among residents. In practice, "broken windows policing" is associated with aggressive, zero-tolerance strategies that risk alienating the community. However, the original theory involved an inherently "human" component that challenged officers to shift from a reactive ("crime fighting") to proactive ("crime prevention") stance and engage directly with the community to promote feelings of safety rather than imposing order:

An officer on foot cannot separate himself from the street people; if he is approached, only his uniform and his personality can help him manage whatever is about to happen. (Kelling \& Wilson, 1982, emphasis added)

An officer's individuality, along with effective communication skills, can elicit transformation not only in the community, but also in officers themselves, given that the proactive stance may contribute to a sense of empowerment and control.

Proactive Alliance also helps officers engage specifically with communities that are difficult to engage rather than entities that are already invested in collaborating with the police, thus allowing authentic engagement with more diverse communities. With these relationships in place, when a problem does arise, the options for addressing it widen and police can "crowdsource" solutions through their collaborative relationships. The Proactive Alliance training draws upon evidence-based principles from counselling psychology to provide an additional set of tools in officers' "duty belts," enabling them to engage in active listening, connect, and problem-solve with community members. Furthermore, while police are taught multiple methods to protect their physical well-being, Proactive Alliance also equips them to more effectively shield their emotional well-being. It teaches the same methods mental health professionals use to manage and cope with their emotional reactions, mitigate and process reactions to traumatic events, and increase resilience, allowing for increased productivity and decreased stress.

\section{The Theory of Proactive Alliance}

Proactive Alliance employs an array of psychological theory and counselling techniques adapted to align with concepts of collaborative order maintenance and procedural justice in the law enforcement environment. The training involves two key stages: (1) strengthening officers' awareness of themselves as agents of change, and (2) teaching them to use this new mindset as a tool to build relationships and establish collaborations. Inherent to both stages are mechanisms to protect the inner emotional self and effectively cope with the stressors of interacting with people in a variety of scenarios, thereby protecting the safety and well-being of both the community and the officer. 


\section{Officers as Agents of Change}

Proactive Alliance is based on the notion that an individual officer's authenticity, personality, and personal judgment are assets, as suggested by broken windows theory. The initial portion of the training provides a forum to process and discuss this concept through exercises aimed at self-exploration and self-awareness. The training presents the officer's self/ personality as a "tool of the trade" that they need to take care of and protect, just as they would their duty weapon. Protecting the self is paramount for officer safety, as it is key to effectively managing stressors and maintaining both physical and emotional safety.

The maintenance of self is achieved through three key elements: interpersonal boundaries, locus of control, and appreciation of the power differential between the police and the community. The concept of interpersonal boundaries originates from Family Systems Theory, which teaches the importance of self-differentiation: the ability to have convictions, principles, and reactions independent of a group (Bowen, 1976, 1978). The ability to identify and respond effectively when a personal boundary has been crossed by a community member or colleague is crucial to maintaining a solid sense of self. Just as therapists are taught how to protect themselves from emotional exposure in the workplace and not become personally involved, while still maintaining the ability to effectively guide and collaborate with clients, Proactive Alliance teaches officers to use their authentic self to connect with others while protecting their emotional wellbeing from harm or interference. Officers learn to establish and maintain interpersonal boundaries, including how to identify when their boundaries have been crossed, and manage their reactions.

Locus of control is a related concept that describes people's ability to control themselves and influence the world around them, rather than simply reacting to crises and feeling controlled by outside forces (Rotter, 1954). Proactive Alliance teaches officers to reorient their perspectives to engage in purposeful prevention by proactively initiating collaboration and preparing for rather than reacting to crises. They are taught to specifically identify feelings, stressors, and personal coping methods to use both in the moment of a stressful event and during the aftermath. The goal of this approach is to increase officers' personal safety, ability to respond appropriately, and ability to cope after the fact, thus supporting wellness and self-care.

Finally, the ability to understand and acknowledge the power differential between the police and the community is another important component of self-awareness and effective community engagement. This is particularly important in communities or with individuals who have had traumatic interactions with the police. A sense of interpersonal safety must be established before any collaboration or working relationship can develop (Herman, 1992). Stakeholders who feel they are not in control (of their choices, feedback, etc.) will feel threatened, which may in turn lead to aggressive behaviour and/or inability to collaborate effectively. Police need to understand these dynamics and how to de-escalate tensions both in the moment and over time for effective and safe collaboration to occur. Furthermore, despite their position of power, officers must also feel safe before they can realize their full potential (Maslow, 1943).
Relationship-Building and Collaboration Skills Training Having established the importance of self as part of the officer's toolkit, Proactive Alliance teaches relationship-building and responsive collaboration skills. These principles are grounded in the Rogerian person-centred approach to counselling psychology (Rogers, 1961). The training adapts the Rogerian concept of unconditional positive regard to the idea of "relationship-based policing" through productive empathy, a central feature of Proactive Alliance.

Unconditional positive regard means accepting and supporting someone without judgment of their behaviour. It is the basis of evidence-based counselling techniques like Motivational Interviewing (MI), which is used in mental health, substance use, and medical settings to evoke actual change by using a person's expressed thoughts about change. These thoughts are elicited by the therapist through listening, normalizing ambivalence, and collaborating rather than directing the change process (Miller, 2017; Miller \& Rollnick, 2013; Prochaska \& DiClemente, 1983). In the policing setting, officers can use the same practical techniques to elicit change in a non-judgmental, non-punitive way when interacting with community members.

Productive empathy involves active listening and dynamic communication techniques to establish rapport, personal connections, and ultimately long-term working relationships. Proactive Alliance teaches officers active listening techniques and how to "reframe" a problem as an opportunity or notice successes before offering constructive feedback. "Reframing" developed out of the concept of "cognitive restructuring/reframing" used in Cognitive-Behavioural Therapy (CBT), another evidence-based psychotherapeutic technique, to challenge cognitive distortions and change thinking to a more positive orientation (Beck, 1976).

Proactive Alliance teaches these techniques to allow officers to work towards responsive collaboration, or the act of working side-by-side in cooperation. Proactive Alliance empowers police to initiate relationships to establish and maintain collaborative changes, saving enforcement only for when absolutely necessary. Rather than the police and community being positioned as adversaries, all stakeholders are involved and accountable. Proactive Alliance supports a proactive, collaborative approach among community stakeholders similar to the concept of wraparound services in child welfare and special education, in which different services are combined to fill gaps to keep children in the most supportive environments. Police can maintain this collaboration by supporting stakeholders to change and control their own behaviour without trying to assert control over them. The latter approach, typical of more aggressive order-maintenance policing, can trigger the natural human reaction to resist when someone-especially an authority figure-tries to control or direct behaviour. On the other hand, collaboration could increase efficiency and safety for both the police and the community.

In policing, as in counselling psychology, it is important to meet stakeholders where they are, not where they "should" or "could" be. This collaborative perspective levels the playing field and sets the stage for realistic expectations. Proactive Alliance teaches officers to adjust their perspective and expectations as stakeholders learn and change in response to guidance and support. Officers learn to give 
collaborative feedback, which focuses first on strengths and highlights what the stakeholder is already doing well before proposing constructive next steps. If officers notice and name these successes, stakeholders feel empowered rather than defeated when receiving feedback. Further, this tactic decreases defensiveness and preserves collaboration by keeping the rapport intact and maintaining or increasing trust and safety.

\section{Prioritizing Community and Officer Safety}

Practising productive empathy, maintaining appropriate interpersonal boundaries, and prioritizing self-awareness and self-care empower police to interact with the community with compassion while also protecting personal vulnerabilities and managing emotions and biases effectively. These skills, in concert with critical thinking, provide the foundation for deliberate restraint: a practice that empowers officers to create an "off-ramp," or course-correct before a power struggle deteriorates, potentially avoiding the need to use force. Relatedly, Proactive Alliance gives guidance on how to intervene when fellow officers engage in inappropriate or potentially dangerous behaviour. Proactive Alliance active bystander intervention training illustrates the Bystander Effect (Latané \& Darley, 1969) in the context of policing, offers police-specific peer intervention strategies, and explores the risks and benefits of peer intervention.

The culmination of the Proactive Alliance training is to become a Proactive Guardian: a police officer who practises deliberate restraint and is empowered to preventively intervene with co-workers when necessary. Acting as a Proactive Guardian is a purposeful decision to prioritize the needs of the community in the spirit of collaboration and the collective good. This shift in perspective cleaves from the trope of the "warrior" officer who approaches the community with defensive fear and an adversarial stance (see Rahr \& Rice, 2015). Rather than warring with the community, police are empowered to invest in it and have an equal interest in its positive change. Further, because Proactive Guardians pursue self-awareness and work to maintain appropriate interpersonal boundaries, they are also well equipped to shield their own emotional vulnerabilities, providing a protective factor that supports officer well-being and mental health. Proactive Alliance teaches officers to consider emotional safety and physical protection to be of equal importance.

\section{CONCLUSION}

This article describes Proactive Alliance, an innovative training program for police officers that builds on criminological theories and evidence-based counselling psychology principles to empower police to build meaningful, long-lasting collaborations with the community. While Proactive Alliance has not yet been rigorously evaluated, we believe the training has the potential to improve officer knowledge, attitudes, and behaviour and community perceptions in a variety of contexts, including large urban agencies, smaller suburban agencies, and specialized departments (e.g., airport/transit police). We are currently developing a randomized controlled evaluation design to study these outcomes, which we aim to implement within the next year. Our goal is to build upon and strengthen the central tenets of COP: community collaboration, problem- solving, and organizational change. Proactive Alliance provides officers with specific, immediately applicable tools to build authentic community engagement that sets the stage for effective problem-solving. The focus on relationship building and resilience strengthens organizational change by equipping officers to thrive under a decentralized model like COP. Individual officers are empowered to become change agents, bringing organizational transformation to the street level.

Strengthening COP implementation could have important benefits for both the community and the police as it improves citizen satisfaction and perceptions of police legitimacy (Gill et al., 2014). Policing strategies that promote satisfaction and legitimacy can increase community members' collective efficacy and willingness to participate in crime prevention (Kochel, 2012; Sargeant et al., 2013). In turn, communities with high levels of collective efficacy and trust in the police tend to have lower crime rates (Jackson \& Sunshine, 2007; Kochel, 2012; Kubrin \& Weitzer, 2003; Weisburd, Davis, et al., 2015; Weisburd et al., 2012; Wells et al., 2006). Getting the police and the community on the same page reduces the risk of both under- and over-enforcement, both of which create hostility and fear, causing citizens to withdraw and lowering collective efficacy (Sampson et al., 1997; Weisburd, Hinkle, et al., 2015). Proactive Alliance provides officers with the tools to develop positive relationships with community members and institutions, with the aim of increasing community support and collaboration.

Furthermore, as we discussed above, COP has the potential to increase factors associated with officers' job satisfaction. However, research in this area has also cautioned that COP may have this effect only because it allows officers to engage with community members when they are not "at their worst," so collaborative work is more positive (McElroy et al., 1990; Skolnick \& Bayley, 1988; Trojanowicz et al., 1998). Consequently, some COP officers choose only to engage with community members with whom they expect to have a positive interaction, rather than those with the greatest need. Proactive Alliance specifically equips officers to work collaboratively with community members who are difficult to engage.

Finally, COP has been described as a foundation or backdrop against which a variety of evidence-based policing strategies that have substantial crime prevention benefits can be implemented (Scheider et al., 2009). Thus, Proactive Alliance has the potential to strengthen not only COP itself, but also support many other effective police innovations-thus promoting police reform and positive outcomes for community members and police officers alike.

\section{ACKNOWLEDGEMENTS}

We are grateful to Dimitrios (Jim) Mastoras, Master Police Officer (Ret.) and co-founder of Safe Night, LLC, and Eric Piza, PhD, John Jay College of Criminal Justice, for their involvement in the development of the Proactive Alliance training and evaluation plan.

\section{CONFLICT OF INTEREST DISCLOSURES}

Molly Mastoras, MA, LPC, is the co-founder of Safe Night, LLC, and developed Proactive Alliance.

\section{AUTHOR AFFILIATIONS}

*Department of Criminology, Law and Society, George Mason University, Fairfax, VA, USA; ${ }^{\dagger}$ Safe Night, LLC, Centreville, VA, USA 


\section{REFERENCES}

Adams, R. E., Rohe, W. M., \& Arcury, T. A. (2002). Implementing community-oriented policing: Organizational change and street officer attitudes. Crime \& Delinquency, 48(3), 399-430. https:// doi.org/10.1177/0011128702048003003

Beck, A. T. (1976). Cognitive therapy and the emotional disorders. Meridian.

Bowen, M. (1976). Theory in the practice of psychotherapy. In P. J. Guerin (Ed.), Family therapy (pp. 42-90). Gardner.

Bowen, M. (1978). Family therapy in clinical practice. Aronson.

Braga, A. A., \& Weisburd, D. (2019). Problem-oriented policing: The disconnect between principles and practice. In D. Weisburd \& A. A. Braga (Eds.), Police innovation: Contrasting perspectives (2nd ed., pp. 182-202). Cambridge University Press.

Braga, A. A., Welsh, B. C., \& Schnell, C. (2015). Can policing disorder reduce crime? A systematic review and meta-analysis. Journal of Research in Crime and Delinquency, 52(4), 567-588. https://doi. org/10.1177/0022427815576576

Brooks, C. (2020). Local police departments: Policies and procedures, 2016 (NCJ 254826). U.S. Department of Justice, Office of Justice Programs, Bureau of Justice Statistics. https://www.bjs.gov/content/ pub/pdf/lpdppl6.pdf

Cordner, G. W. (1999). Elements of community policing. In L. K. Gaines \& G. W. Cordner (Eds.), Policing perspectives: An anthology (pp. 137-149). Roxbury.

Eck, J. E., \& Rosenbaum, D. P. (1994). The new police order: Effectiveness, equity, and efficiency in community policing. In D. P. Rosenbaum (Ed.), The challenge of community policing: Testing the promises (pp. 3-23). Sage.

Gill, C., Weisburd, D., Telep, C. W., Vitter, Z., \& Bennett, T. (2014). Community-oriented policing to reduce crime, disorder and fear and increase satisfaction and legitimacy among citizens: A systematic review. Journal of Experimental Criminology, 10(4), 399-428. https://doi.org/10.1007/s11292-014-9210-y

Goldstein, H. (1990). Problem-oriented policing. McGraw-Hill.

Greene, J. R. (1989). Police officer job satisfaction and community perceptions: Implications for community-oriented policing. Journal of Research in Crime \& Delinquency, 26(2), 168-183. https://doi. org/10.1177/0022427889026002004

Herman, J. (1992). Trauma and recovery. Basic Books.

Hyland, S. S., \& Davis, E. (2019). Local police departments, 2016: Personnel (NCJ 252835). U.S. Department of Justice, Office of Justice Programs, Bureau of Justice Statistics. https://www.bjs.gov/content/ pub/pdf/lpd16p.pdf

Jackson, J., \& Sunshine, J. (2007). Public confidence in policing: A neoDurkheimian perspective. The British Journal of Criminology, 47(2), 214-233. https://doi.org/10.1093/bjc/azl031

Johnson, R. R. (2012). Police officer job satisfaction: A multidimensional analysis. Police Quarterly, 15(2), 157-176. https://doi.org/10.1177/ 1098611112442809

Kelling, G. L., \& Wilson, J. Q. (1982). Broken windows: The police and neighborhood safety. Atlantic Monthly, March, 1-9.

Kochel, T. R. (2012). Can police legitimacy promote collective efficacy? Justice Quarterly, 29(3), 384-419. https://doi.org/10.1080/074 18825.2011 .561805

Kubrin, C. E., \&Weitzer, R. (2003). New directions in social disorganization theory. Journal of Research in Crime and Delinquency, 40(4), 374-402. https://doi.org/10.1177/0022427803256238

Latané, B., \& Darley, J. M. (1969). Bystander "apathy." American Scientist, 57(2), 244-268

Lord, V. B. (1996). An impact of community policing: Reported stressors, social support, and strain among police officers in a changing police department. Journal of Criminal Justice, 24(6), 503-522. https:// doi.org/10.1016/S0047-2352(96)00036-0

Lum, C., Koper, C. S., Gill, C., Hibdon, J., Telep, C. W., \& Robinson, L. (2016). An evidence-assessment of the recommendations of the President's Task Force on 21st Century Policing: Implementation and research priorities. International Association of Chiefs of Police. http://cebcp.org/wp-content/evidence-based-policing/IACP-GMUEvidence-Assessment-Task-Force-FINAL.pdf

Lurigio, A. J., \& Skogan, W. G. (1994). Winning the hearts and minds of police officers: An assessment of staff perceptions of community policing in Chicago. Crime \& Delinquency, 40(3), 315-330. https:// doi.org/10.1177/0011128794040003002

Maslow, A. H. (1943). A theory of human motivation. Psychological Review, 50(4), 370-396. https://doi.org/10.1037/h0054346

Mastrofski, S. D., Willis, J. J., \& Kochel, T. R. (2007). The challenges of implementing community policing in the United States. Policing, 7(2), 223-234. https://doi.org/10.1093/police/pam026

Mastrofski, S. D., Worden, R. E., \& Snipes, J. B. (1995). Law enforcement in a time of community policing. Criminology, 33(4), 539-563. https://doi.org/10.1111/i.1745-9125.1995.tb01189.x

McElroy, J. E., Cosgrove, C. A., \& Sadd, S. (1990). CPOP: The research. An evaluative study of the New York City Community Patrol Officer Program. Vera Institute of Justice. http://www.vera.org/pubs/ cpop-research-evaluative-study-new-york-city-community-patrolofficer-program

Miller, W. R. (2017). Systematic and meta-analyses of research on motivational interviewing. Motivational Interviewing Network of Trainers. http://www.motivationalinterviewing.org/sites/default/ files/mi_research_reviews_2017.pdf

Miller, W. R., \& Rollnick, S. (2013). Motivational interviewing: Helping people change. The Guilford Press.

Moore, M. H. (1992). Problem-solving and community policing. Crime and Justice, 15, 99-158. https://doi.org/10.1086/449194

Morabito, M. S. (2010). Understanding community policing as an innovation: Patterns of adoption. Crime \& Delinquency, 56 (4), 564-587. https://doi.org/10.1177/0011128707311643

Morash, M., Haarr, R., \& Kwak, D.-H. (2006). Multilevel influences on police stress. Journal of Contemporary Criminal Justice, 22 (1), 26-43. https://doi.org/10.1177/1043986205285055

Office of Community Oriented Policing Services. (2014). Community policing defined. U.S. Department of Justice, Office of Community Oriented Policing Services. https://cops.usdoj.gov/pdf/vets-to-cops/ e030917193-cp-defined.pdf

Pelfrey, W. V. (2004). The inchoate nature of community policing: Differences between community policing and traditional police officers. Justice Quarterly, 21(31, 579-601. https://doi.org/10. 1080/07418820400095911

Prochaska, J. O., \& DiClemente, C. C. (1983). Stages and processes of self-change of smoking: Toward an integrative model of change. Journal of Consulting and Clinical Psychology, 51 (3), 390-395.

Rahr, S., \& Rice, S. K. (2015). From warriors to guardians: Recommitting American police culture to democratic ideals (NCJ 248654). U.S. Department of Justice, Office of Justice Programs, National Institute of Justice. https://www.ncirs.gov/pdffilesl/nii/248654.pdf

Rogers, C. (1961). On becoming a person. Houghton-Mifflin.

Rosenbaum, D. P., Yeh, S., \& Wilkinson, D. L. (1994). Impact of community policing on police personnel: A quasi-experimental test. Crime \& Delinquency, 40(3), 331-353. https://doi.org/10.1177/ 0011128794040003003

Rotter, J. B. (1954). Social learning and clinical psychology. Prentice-Hall. Sampson, R.J., Raudenbush, S. W., \& Earls, F. (1997). Neighborhoods and 
violent crime: A multilevel study of collective efficacy. Science, 27715328) 918-924. https://doi.org/10.1126/science.277.5328.918

Sargeant, E., Wickes, R., \& Mazerolle, L. (2013). Policing community problems: Exploring the role of formal social control in shaping collective efficacy. Australian \& New Zealand Journal of Criminology, 46(1), 70-87. https://doi.org/10.1177/ 0004865812470118

Scheider, M. C., Chapman, R., \& Schapiro, A. (2009). Towards the unification of policing innovations under community policing. Policing: An International Journal of Police Strategies \& Management, 32(4), 694-718. https://doi.org/10.1108/13639510911000777

Skogan, W. G. (2006). The promise of community policing. In D. Weisburd \& A. A. Braga (Eds.), Police innovation: Contrasting perspectives (pp. 27-43). Cambridge University Press.

Skogan, W. G., \& Frydl, K. (Eds.). (2004). Fairness and effectiveness in policing: The evidence. National Academies Press.

Skogan, W. G., \& Hartnett, S. M. (1997). Community policing, Chicago style. Oxford University Press.

Skolnick, J. H., \& Bayley, D. H. (1988). Community policing: Issues and practices around the world. U.S. Department of Justice, Office of Justice Programs, National Institute of Justice.

Telep, C. W., \& Weisburd, D. (2016). Policing. In D. Weisburd, D. P. Farrington, \& C. Gill (Eds.), What works in crime prevention and rehabilitation: Lessons from systematic reviews (pp. 137-168). Springer. https://doi.org/10.1007/978-1-4939-3477-5_5

Trojanowicz, R. C., Kappeler, V. E., Gaines, L. K., \& Bucqueroux, B. (1998). Community policing: A contemporary perspective (2nd ed.). Anderson.

Weisburd, D., Davis, M., \& Gill, C. (2015). Increasing collective efficacy and social capital at crime hot spots: New crime control tools for police. Policing: A Journal of Policy and Practice, 9(3), 265-274. https://doi.org/10.1093/police/pav019

Weisburd, D., Groff, E. R., \& Yang, S.-M. (2012). The criminology of place: Street segments and our understanding of the crime problem. Oxford University Press.

Weisburd, D., Hinkle, J. C., Braga, A. A., \&Wooditch, A. (2015). Understanding the mechanisms underlying broken windows policing: The need for evaluation evidence. Journal of Research in Crime and Delinquency, 52(4), 589-608. https://doi.org/10.1177/0022427815577837

Weisburd, D. L., Braga, A. A., \& Majmundar, M. K. (2021). What do we know about proactive policing's effects on crime and community: Drawing conclusions from a National Academy of Sciences, Engineering, and Medicine report. In D. L. Weisburd, T. Jonathan, B. Hasisi, \& G. Perry (Eds.), The future of evidence-based policing. Cambridge University Press.

Weisburd, D., Telep, C. W., Hinkle, J. C., \& Eck, J. E. (2010). Is problemoriented policing effective in reducing crime and disorder? Criminology \& Public Policy, 9(1), 139-172. https://doi.org/10.1111/i.17459133.2010.00617.x

Wells, W., Schafer, J. A., Varano, S. P., \& Bynum, T. S. (2006). Neighborhood residents' production of order: The effects of collective efficacy on responses to neighborhood problems. Crime \& Delinquency, 52(4), 523-550. https://doi.org/10.1177/0011128705284681

Zhao, J. S., He, N., \& Lovrich, N. (2002). Predicting five dimensions of police officer stress: Looking more deeply into organizational settings for sources of police stress. Police Quarterly, 5(1), 43-62. https:// doi.org/10.1177/109861110200500103

Zhao, J., Thurman, Q., \& He, N. (1999). Sources of job satisfaction among police officers: A test of demographic and work environment models. Justice Quarterly, 16(1), 153-173. https://doi.org/10.1080/ 07418829900094091 